\title{
Influence of Chelated Micronutrients on Yield and Quality of Potato Tubers
}

\author{
Oksana Starovoitova1, Viktor Starovoitov¹, and Aleksandra Manokhina² \\ ${ }^{1}$ Lorch Potato Research Institute, Kraskovo, Russia \\ ${ }^{2}$ Russian State Agrarian University - Moscow Agricultural Academy named after K.A. Timiryazev, \\ Moscow, Russia
}

\section{Abstract}

The purpose of this research was evaluation of influence of chelate compounds of micronutrients on yield and state tubers of mid-season potato variety Kolobok during storage. The research was conducted on the fields with sod-podzolic sandy loam soil in 2016 and 2017 years. During the research one tuber processing and two foliar processing were done before planting and during vegetation respectively. The experiment had two control groups, the first group was not treated at all and the second group was treated with water. The organization of field experiment, counting and observation were done according to requirements of methods of field experiment and

Corresponding Author: Aleksandra Manokhina alexman80@list.ru

Received: 25 October 2019 Accepted: 15 November 2019 Published: 25 November 2019

Publishing services provided by Knowledge E

(c) Oksana Starovoitova et al. This article is distributed under the terms of the commons Attribution License, which permits unrestricted use and redistribution provided that the original author and source are credited

Selection and Peer-review under the responsibility of the AgroSMART 2019 Conference Committee.

\section{G OPEN ACCESS}

"Methods of investigation of potato varieties". On average of two years groups treated with drugs, which contain chelate compounds of micronutrients, had 4.4 and 4.7 main stems per bush respectively that was more than in control groups. The application of the drugs increased marketable yield by 3.5--3.7 t/ha (13.5--14.2 \%). On average of two years groups treated with sulfur-containing drug had the biggest marketable yield that was 9.9 tubers per bush (1.5 tubers per bush or $17 \%$ more than first control group). The obtained result of the experiment means that these drugs are worth using during potato cultivation.

Keywords: potato, chelate compounds of micronutrients, biometric, yield, coefficient of reproduction, state of potato tubers during storage

\section{Introduction}

Potato is an important national food product. According to the official statistics Russian Federation almost completely provides itself with potatoes produced inside the country. In the structure of consumption of potato more than $50 \%$ of its production is used for cooking various potato meals by both common people and modern food industry. In Russia yield of potato varieties is not even $50 \%$ of potential yield, so researches on inventing and proving technologies of cultivation that can increase yield and quality of potato tubers are still carried out [1]. It is necessary to think over different variants of foliar treatment [2]. Different foliar treatments with micronutrients that are in from of 
chelate fertilizer can significantly increase yield and content of the micronutrients in tubers [3--6].

Thus conducting researches on inventing technologies of potato cultivation with help of innovative drugs "Teuton" and "Hilton Extra", that were used to increase yield, coefficient of reproduction and state of potato tubers during storage, is actual.

\section{Methods and Equipment}

The research was conducted at experimental base Korenevo of Lyubertsy district of Moscow oblast in the period 2016 and 2017 years. The evaluation of correlation between changes of yield, coefficient of reproduction, state of potato tubers during storage and application of following innovative drugs: "Hilton Extra" that contains chelate compounds of various micronutrients, such as iron, zinc, manganese, copper, molybdenum, cobalt and boron, and sulfur-containing "Teuton" was one of the research objectives [7].

Sulfur takes one of the highest positions in the list of nutrients that greatly influence on metabolism of plants, right after nitrogen, phosphorus and potassium. Sulfur content in plants is $0.005-1.0 \%$ of dry mass $[8,9]$. As for manganese, there are some ideas that its content influences on growth and morphogenesis of potato organs [10], but at the same moment high manganese content in nutrition worsen absorption of other micronutrients [11]. Iron plays a great role in metabolism of plants and also influence on activity and characteristics of metabolism of absorbed nutrients [12, 13]. Potato has a medium sensitivity to zinc [14]. Zinc positively influences on producing of auxins and chlorophyll [13]. Shortage of zinc decreases intensity of accumulation of organic matter, so plants worse grow and develop. Adding zinc in nutritional solute increases absorption of nitrogen, potassium, manganese, and molybdenum. Zinc fastens growth of potato, shortens vegetative period and increases immunity of potato against phytophthora infestans (late blight) [14]. The usage of copper can increase potato protection against damping off and harsh environmental conditions [13]. Copper fastens tubers formation, increases potato protection against black leg, potato scab and internal rust spot [14]. Falling of flowers and ovaries, small yield of seeds and fruits despite comfortable conditions are usual consequences of boron shortage $[11,13]$. According to results of German scientists Wulkow A., Pawelzik E. and Heckl B calcium and boron are antagonists. The ratio of calcium to boron between 15 to 1 and 100 to 1 causes normal growth of potato, but when the ratio of calcium to boron is bigger than 100 to 1 , shortage of born is observed [15]. Plants get molybdenum in form of molybdates or in form of 
chelate compounds. Molybdenum becomes more mobile, when $\mathrm{pH}$ is increased [10]. According to data, that have been accumulated up to nowadays, cobalt content in plants is between 0.01 and $0.85 \mathrm{mg} / \mathrm{kg}$ of dry mass and on average it is $0.2 \mathrm{mg} / \mathrm{kg}$ of dry mass [13]. Shortage, optimum and excess of cobalt content are 0.02, 0.03--1.00 and 1.01--50.00 $\mathrm{mg} / \mathrm{kg}$ of dry mass respectively [11].

Field, where experiment was conducted, was medium cultivated and had sodpodzolic sandy loam soil. Preliminary experiment was done according to the scheme with application of systematic plot placing method under conditions of three-field system of crop rotation. Predecessors of potato were grasses and cereals. Research had 4 times replication. The area of record plot was $5.6 \mathrm{~m}^{2}(0.75 \times 7.5 \mathrm{~m})$ Density of planting was 44.4 thousand of tubers per hectare.

Before planting potato tubers were treated with water (in the second control group) or by drug "Teuton" or "Hilton Extra" to raise quality of tubers, stimulate and improve growth and sprouting of buds. Consumption of drug solute was 10 liters per ton of tubers (ratio of drug to water was $30 \mathrm{ml}$ to 10 liters). Elite tubers of mid-season potato variety Kolobok were planted into precut ridges at depth of 12--14 cm by MTZ-82 (tractor model of 1.4 traction class) with SKTS (quadruple potato and Jerusalem artichoke planter) and by MTZ-82 with quadruple cloning potato planter on 9 June 2016 and 15 May 2017 respectively. The tubers were medium sized, they were not germinated and had max transverse tuber diameter (among other diameters of each tuber) of $30--50 \mathrm{~mm}$

To prepare soil of the field primary tillage and secondary tillage were done. The primary tillage, whose depth was 18--25 cm, was done by MTZ-82 with PLN (mounted plough with a ploughshare) in autumn. The secondary tillage, whose depth was 12-6 $\mathrm{cm}$, was done by MTZ-82 with BDT (heavy disk harrows) in spring. In addition mineral NPK fertilizer (16\%-16\%-16\%) was locally applied by MTZ-82 with KRN (mounted cultivator and plant feeder) during ridge making (N4OP4OK40) and during taking care of plants (N100P100K100).

During such phases of vegetative period as sprouting and budding-start of flowering spraying plants were sprayed with water and innovative drugs "Teuton" or "Hilton Extra" according to scheme. The consumption of drug solute was $300 \mathrm{I} /$ ha (ratio of drug to water was $15 \mathrm{ml}$ to 10 liters). Such herbicides as "Zenkor", "Mais" and "H9O" were used against weed. Plants were once sprayed with drug "Aktara" to protect them against Colorado potato beetle. The consumption of drug was $60 \mathrm{~g} / \mathrm{ha}$. During vegetation 3 chemical treatments with drug "Ridomil Gold" against phytophthora infestans(late blight) and alternaria solani(alternariosis) were done. The first treatment was done during flowering and subsequent treatments were done 10-14 days after previous one. 
The organization of field experiment, counting and observation were done according to requirements of methods of field experiment [16] and "Methods of investigation of potato varieties" [17].

Average temperature of air during vegetative period of 2017 year was $16.2^{\circ} \mathrm{C}$. In 2016 it was $18.6{ }^{\circ} \mathrm{C}$, whereas norm of temperature of air is $16.5^{\circ} \mathrm{C}$. Sum of all precipitation during vegetative period of 2017 year was $378.4 \mathrm{~mm}$ or $145.3 \%$ of norm that is 260.5 $\mathrm{mm}$. In 2016 Sum of all precipitation during vegetative period was $470.2 \mathrm{~mm}$ or $180.5 \%$ of norm. In 2017 year Selyaninov Hydrothermal Coefficient was 2.06 (wet). In 2016 year it was 2.13 (very wet) whereas norm is 1.3--1.4 [18]

\section{Results}

Biometrics of potato aboveground part is presented in Table 1.

The data about marketable yield in different groups are displayed in Figure 1.

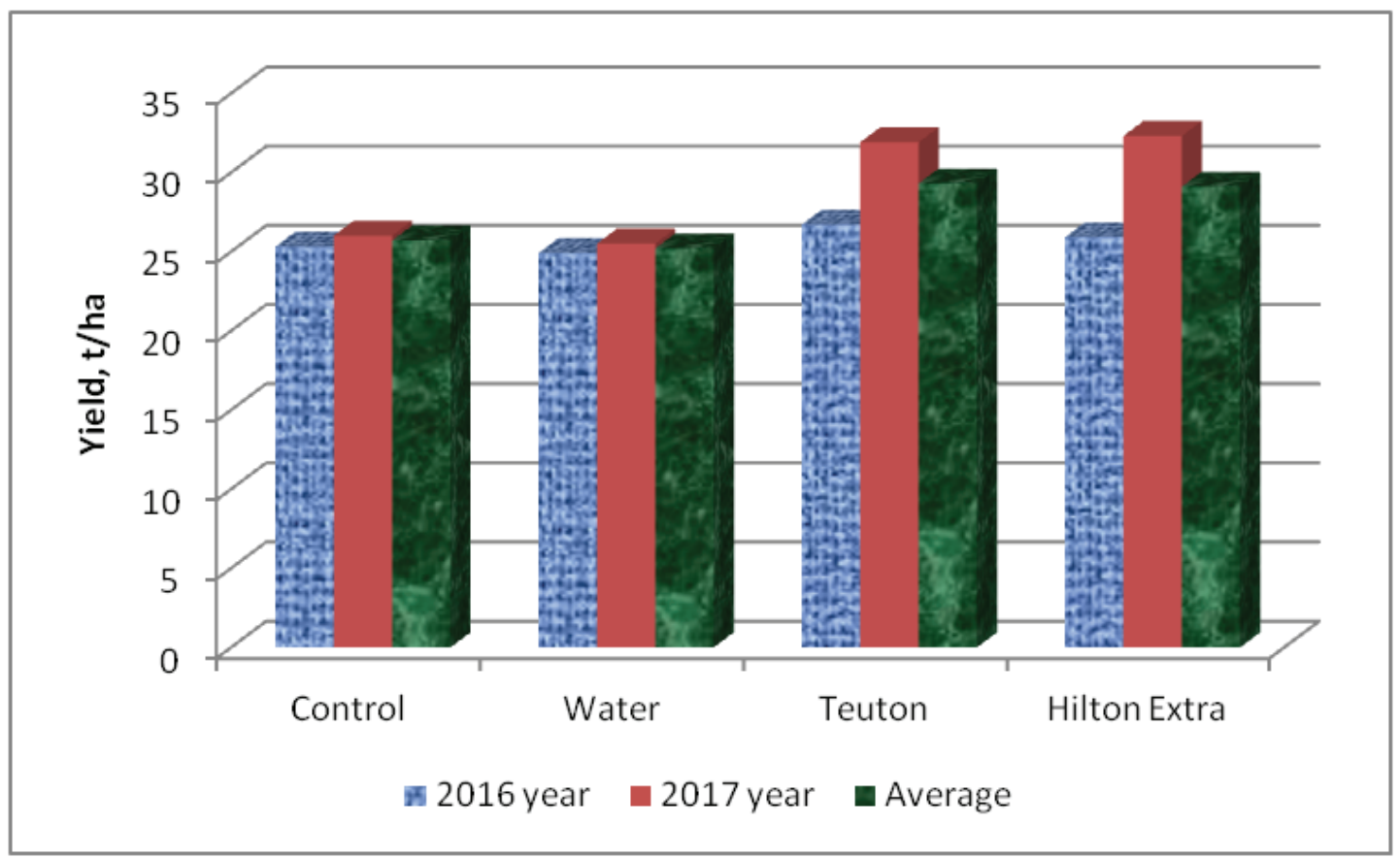

Figure 1: Marketable yield of potato variety Kolobok, t/ha.

In Table 2 the coefficient of reproduction of marketable tubers is presented.

As for influence the drugs on potato state during storage, data about it you can find in Table 3.

Control difference is difference between chosen group and control group. 
TABLE 1: Biometric characteristics of potato tops during flowering phase.

\begin{tabular}{|c|c|c|c|c|c|}
\hline \multirow[t]{2}{*}{ Variant number } & \multirow[t]{2}{*}{ Drug } & \multicolumn{4}{|c|}{ Characteristics of tops growth } \\
\hline & & $\begin{array}{l}\text { Amount of } \\
\text { stems, pcs }\end{array}$ & Height, cm & $\begin{array}{l}\text { Mass of tops, } \mathrm{g} \\
\text { per bush }\end{array}$ & $\begin{array}{c}\text { Leaf area, } \mathrm{m}^{2} \\
\text { per bush }\end{array}$ \\
\hline \multicolumn{6}{|c|}{ In 2016 year } \\
\hline 1 & Control & 3.4 & 64.8 & 612 & 1.43 \\
\hline 2 & Water & 4.0 & 63.8 & 682 & 1.88 \\
\hline 3 & Teuton & 4.8 & 58.5 & 656 & 1.69 \\
\hline 4 & Hilton Extra & 6.4 & 55.3 & 552 & 1.33 \\
\hline \multicolumn{2}{|c|}{ Average } & 4.7 & 60.6 & 626 & 1.58 \\
\hline \multicolumn{2}{|c|}{$\mathrm{LSD}_{05}$} & 1.13 & 3.89 & 49.26 & 0.22 \\
\hline \multicolumn{6}{|c|}{ In 2017 year } \\
\hline 1 & Control & 3.3 & 42.3 & 214 & 0.35 \\
\hline 2 & Water & 3.6 & 41.5 & 236 & 0.35 \\
\hline 3 & Teuton & 3.9 & 43.3 & 244 & 0.41 \\
\hline 4 & Hilton Extra & 3.0 & 43.3 & 201 & 0.44 \\
\hline \multicolumn{2}{|c|}{ Average } & 3.5 & 42.6 & 224 & 0.39 \\
\hline \multicolumn{2}{|c|}{$\mathrm{LSD}_{05}$} & 0.34 & 0.75 & 17.12 & 0.04 \\
\hline \multicolumn{6}{|c|}{ Average of 2016 and 2017} \\
\hline 1 & Control & 3.4 & 53.6 & 713 & 0.89 \\
\hline 2 & Water & 3.8 & 52.7 & 459 & 1.12 \\
\hline 3 & Teuton & 4.4 & 50.9 & 450 & 1.05 \\
\hline 4 & Hilton Extra & 4.7 & 49.3 & 376.5 & 0.89 \\
\hline \multicolumn{2}{|c|}{ Average } & 4.1 & 51.6 & 425 & 0.99 \\
\hline
\end{tabular}

TABLE 2: Coefficient of marketable tuber reproduction, tubers per bush.

\begin{tabular}{|c|c|c|c|c|c|c|c|c|}
\hline \multirow{2}{*}{$\begin{array}{l}\text { Varient } \\
\text { number }\end{array}$} & \multirow[t]{2}{*}{ Drug } & \multicolumn{2}{|c|}{ During flowering phase } & \multicolumn{5}{|c|}{ During harvest } \\
\hline & & In 2016 & In 2017 & $\ln 2016$ & In 2017 & Average & $\begin{array}{c}\text { Control } \\
\text { difference }\end{array}$ & $\begin{array}{c}\% \text { of } \\
\text { control }\end{array}$ \\
\hline 1 & Control & 4.8 & 3.9 & 7.0 & 9.9 & 8.5 & & \\
\hline 2 & Water & 4.4 & 3.1 & 8.1 & 10.2 & 9.2 & 0.7 & 108 \\
\hline 3 & Teuton & 5.3 & 4.3 & 8.9 & 10.9 & 9.9 & 1.5 & 117 \\
\hline 4 & Hilton & 5.3 & 3.1 & 8.6 & 9.5 & 9.1 & 0.6 & 107 \\
\hline \multicolumn{2}{|c|}{ Average } & 5.0 & 3.6 & 8.2 & 10.1 & & & \\
\hline \multicolumn{2}{|c|}{$\mathrm{LSD}_{05}$} & 0.38 & 0.52 & 0.72 & 0.51 & & & \\
\hline
\end{tabular}


TABLE 3: Correlation between usage of the drugs and state of potato tubers during storage, \%.

\begin{tabular}{|c|c|c|c|c|c|}
\hline $\begin{array}{l}\text { Variant } \\
\text { number }\end{array}$ & Drug & Total losses & $\begin{array}{l}\text { Losses } \\
\text { cause by } \\
\text { drying }\end{array}$ & $\begin{array}{l}\text { Losses } \\
\text { caused by } \\
\text { sprouts }\end{array}$ & $\begin{array}{c}\text { Losses } \\
\text { caused by } \\
\text { rot }\end{array}$ \\
\hline \multicolumn{6}{|c|}{ Average of winter period of 2016 and 2017 years } \\
\hline 1 & Control & 4.90 & 4.51 & 0.24 & 0.16 \\
\hline 2 & Water & 4.66 & 4.16 & 0.30 & 0.20 \\
\hline 3 & Teuton & 4.31 & 3.98 & 0.16 & 0.18 \\
\hline 4 & Hilton Extra & 4.42 & 3.74 & 0.14 & 0.53 \\
\hline \multicolumn{2}{|c|}{ Average } & 4.60 & 4.1 & 0.2 & 0.3 \\
\hline \multicolumn{2}{|c|}{$\mathrm{LSD}_{05}$} & 0.23 & 0.28 & 0.06 & 0.15 \\
\hline \multicolumn{6}{|c|}{ Average of winter period of 2017 and 2018 years } \\
\hline 1 & Control & 5.49 & 4.67 & 0.15 & 0.67 \\
\hline 2 & Water & 6.10 & 5.41 & 0.29 & 0.67 \\
\hline 3 & Teuton & 5.20 & 4.39 & 0.19 & 0.62 \\
\hline 4 & Hilton Extra & 5.37 & 4.40 & 0.21 & 0.76 \\
\hline \multicolumn{2}{|c|}{ Average } & 5.5 & 4.7 & 0.2 & 0.7 \\
\hline \multicolumn{2}{|c|}{$\mathrm{LSD}_{05}$} & 0.34 & 0.30 & 0.05 & 0.05 \\
\hline \multicolumn{6}{|c|}{ Average of both winter periods } \\
\hline 1 & Control & 5.20 & 4.59 & 0.20 & 0.42 \\
\hline 2 & Water & 5.38 & 4.65 & 0.30 & 0.44 \\
\hline 3 & Teuton & 4.76 & 4.19 & 0.18 & 0.40 \\
\hline 4 & Hilton Extra & 4.90 & 4.07 & 0.18 & 0.65 \\
\hline
\end{tabular}

\section{Discussion}

As a rule the intensity of yield accumulation, yield and state of potato tubers during storage are determined by size of tops. Under normal conditions of growth there is a direct correlation between productivity of potato plants and size of their aboveground part. The more massive bush is, the higher yield is. However not in all cases the most massive bush has the highest yield [19].

According to the data obtained during 2016, we could note that the drugs positively influenced on amount of main stems that influenced on the yield. As it is known, the more main stems there are, the bigger yield is [20]. Plants treated with drug "Hilton Extra" had 6.4 main stems per bush that was the largest amount of stems per bush among other groups, plants treated with "Teuton" had 4.8 main stems per bush and plants in control group had only 3.4 main stems per bush. We also noted that, despite 
the fact of being planted late, all plants quickly passed phases of vegetation. Under conditions of normal planting during early days of May sprouts appears in 3 or 4 weeks after planting, while in our experiment during the measuring of their height it was noted that in 3 weeks after planting sprouts had not only appeared, but also had grown a little bit. Plants treated with drug "Hilton Extra" were the highest and their height was under 13--17 cm, plants treated with drug "Teuton" were not higher than 7--13 cm, whereas plants treated with water were not higher than $11-13 \mathrm{~cm}$ and plants in control group had height under 6-12 cm.

To flowering phase plants treated with drugs "Hilton Extra" and "Teuton" had more main stems that were not higher or bigger than main stems of both control groups. We noted that all plants were higher and bigger and had more assimilative leaf surface (area of leaves) than they should under normal meteorological conditions or in dry years, because under such conditions in flowering phase plants' height is $35--50 \mathrm{~cm}$, mass of their tops is $200--400 \mathrm{~g}$ per bush and area of leaves is $0.40--0.70 \mathrm{~m}^{2}$ per bush [21].

In 2017 year that was not as wet as 2016 plants treated with "Hilton Extra" had more main stems than plants in control groups, but all plants had approximately the same height of $41.5--44.8 \mathrm{~cm}$. Plants treated with drugs "Hilton Extra" and "Teuton" had the height of $43.3 \mathrm{~cm}$ and were the highest. Plants treated with drug "Teuton" were the biggest and mass of their tops was $244 \mathrm{~g}$ per bush. Application of the drugs increased assimilative surface of leaves to $0.41--0.44 \mathrm{~m}^{2}$ per bush.

On average of two years plants treated with drugs "Hilton Extra" and "Teuton" had more main stems ( 4.4 and 4.7 main stems per bush respectively) than plants in control groups, whereas plants treated with water and plants in control group were the highest (53.6 and $52.7 \mathrm{~cm}$ high respectively). Yield is the main factor of evaluation of crop cultivation events $[19,20,22]$. On average of two years in flowering phase all plants had approximately the same mass of marketable tubers, that was $0.151--0.157 \mathrm{~g}$ per bush, but during the harvest there was considerable difference between control groups and groups treated with the drugs (Figure 1).

Usually harvest is carried out 90 days after planting [20], but in 2016 year the experiment was carried out considerably later, so harvest was carried out on 1 September, that was only 83 days after planting. Plants still were green and only started to wilt that meant that formation of tubers was not in its last stage.

Analyzing Figure 1, it can be noted that usage of drug "Teuton" increased yield by 1.4--5.9 t/ha and usage of drug "Hilton Extra" increased yield by 0.6-6.3 t/ha, whereas usage of water did not reliably increased yield. In 2016 year average yield was $25.7 \mathrm{t} / \mathrm{ha}$ and LSD05 was $0.68 \mathrm{t} / \mathrm{ha}$, while in 2017 average yield was 28.9 t/ha and LSD05 was 3.18 
t/ha. In both 2016 and 2017 years plants treated with water had less marketable yield than plants in control group. It was probably caused by some meteorological conditions that were very wet in both 2016 and 2017 years.'

On average of two years usage of drug "Teuton" increased yield by $3.7 \mathrm{t} / \mathrm{ha}$ or 14.2 $\%$ and usage of drug "Hilton Extra" increased by $3.5 \mathrm{t} /$ ha or $13.5 \%$. These results mean that these drugs are worth usage during potato cultivation.

In rainy 2016 year average percentage of marketability was $97 \%$ and in 2017 it was $98 \%$.

Coefficient of reproduction is important factor of variety evaluation. In 2016 the plants treated with drugs "Teuton" and "Hilton Extra" had the highest coefficient of reproduction that was equal to 11.1. During flowering difference between coefficients of reproduction control groups and groups treated with drugs was 0.6--2.4 (Table 2), but during harvest it was already 2.9. The data obtained in 2016 year proved that the more main stems bush had the more tubers it had [20]. Plants treated with drugs had 1.4--3.0 more main stems per bush than plants in control groups.

In 2017 year plants treated with drug "Teuton" had the highest coefficient of marketable tuber reproduction, that was equal to 10.9 tubers per bush, whereas plants treated with "Hilton Extra" had fewer tubers, but they were bigger.

On average of two years plants treated with drug "Teuton" had the largest output of marketable tubers that was equal to 9.9 tubers per bush or $117 \%$ of output of control groups.

Total losses during storage are strictly connected with both storage conditions and state of stored tubers. The influence of different combinations of technological methods on storage quantity of tubers was investigated by us in two autumn-winter periods of 2016--2017 and 2017--2018 years. According to the obtained data (Table 3), total losses during storage depended on both conditions of vegetative period and technological methods of cultivation.

The drugs positively influenced on state of tubers during storage. On average of two years of storage group treated with drug "Teuton" had the lowest total losses of 4.76 $\%$, whereas control groups had total losses of 5.20--5.38\%. 


\section{Conclusion}

During phase of flowering mass of marketable tubers was approximately the same (0.151--0.157 g per bush) in every group, but during harvest there were considerable difference between control groups and groups treated with the drugs.

The use of drug "Teuton" increased yield by $3.7 \mathrm{t} / \mathrm{ha}$ or $14.2 \%$ and usage of drug"Hilton Extra" increased by $3.5 \mathrm{t} /$ ha or $13.5 \%$. These results means that these drugs are worth usage during potato cultivation

The plants treated with the drugs had more marketable tubers, that is $97.5 \%$ of yield than plants in control groups, that had $97.0 \%$ of yield

On average of two years plants treated with drug "Teuton" had the largest output of marketable tubers that was equal to 9.9 tubers per bush or $117 \%$ of output of control groups.

On average of two years spoilage rate of group treated with "Teuton" was the least among other groups and was $4.76 \%$, whereas spoilage rate of control group was between 5.20 and $5.38 \%$.

\section{Acknowledgement}

The authors would like to thank their colleague for their contribution and support to the research. They are also thankful to all the reviewers who gave their valuable inputs to the manuscript and helped in completing the paper.

\section{Conflict of Interest}

The authors have no conflict of interest to declare.

\section{References}

[1] Starovoitov, V.I., Pavlova, O.A., Voronov, N.V. (2007). Prospects of Potato Growing Techniques in wide Rows. Potato production and innovative technologies, ed. A.J. Haverkort, B.V. Anisimov. Wageningen, pp. 246--251.

[2] Korshunov, A.V. (2001). Upravlenie urozhaem i kachestvom kartofelja. Moscow, $369 \mathrm{p}$. 
[3] Gaj, R., Murawska, B., Fabisiak-Spychaj, E. et al. (2018). The impact of cover crops and foliar application of micronutrients on accumulation of macronutrients in potato tubers at technological maturity stage. European Journal of Horticultural Scienc, vol. 83, Vypusk 6, pp. 345--355.

[4] Zhevora, S.V., Fedotova, L.S., Timoshina, N.A., Knjazeva, E.V. (2018). Jeffektivnost' reguljatorov rosta pri vozdelyvanii kartofelja. Kartofel' i ovoshhi, vol. 12, pp. 21--24.

[5] Usanova, Z.I., Buljukina, O.A. (2017). Vlijanie kompleksonatov mikrojelementov na formirovanie urozhajnosti topinambura. Sbornik nauchnyh trudov po materialam Mezhdunarodnoj nauchno-prakticheskoj konferencii "Povyshenie upravlencheskogo, jekonomicheskogo, social'nogo, innovacionno-tehnologicheskogo i tehnicheskogo potenciala predprijatij i otraslej APK". pp. 8--11.

[6] Cheremisin, A.I., Jakimova, I.A. (2018). Vlijanie nekornevyh podkormok na produktivnost' ozdorovlennogo ishodnogo materiala rannespelyh sortov kartofelja. Vestnik Burjatskoj gosudarstvennoj sel'skohozjajstvennoj akademii im. V.R. Filippova, vol. 4(53), pp. 199--204.

[7] Makarenkov, D.A., Nazarov, V.I., Shelakov, M.N., Popov, A.P. (2018). Primenenie helatnyh form mikrojelementov $v$ tehnologii proizvodstva granulirovannyh udobrenij NPK. Sbornik materialov VII Vserossijskoj konferencii c mezhdunarodnym uchastiem "Aktual'nye voprosy himicheskoj tehnologii i zashhity okruzhajushhej sredy", pp. 139--140.

[8] Kurkaeva, V.T., Sheudzhen, A.H. (2000). Agrohimija. Majkop: GURIPP «Adygeja», 552 p.

[9] Novikov, N.N. (2014). Biohimicheskie osnovy formirovanija kachestva produkcii rastenievodstva. Uchebnoe posobie. Moscow: Izd-vo RGAU_MSHA imeni K.A. Timirjazeva, $194 \mathrm{p}$.

[10] Golubev, I.M. (1993). O geohimicheskoj jekologii mikrojelementov, tjazhelyh metallov. Problemy jekologii v sel. hoz-ve. Penza, ch. 1, pp. 28--30.

[11] Kabata-Pendias, A., Pendias, H. (1989). Mikrojelementy $v$ pochvah i rastenijah. Moscow: Mir, 439 p.

[12] Bitjuckij, N.P. (2005). Neobhodimye mikrojelementy rastenij. Uchebnik. St. Petersburg: izd-vo DEAN, 256 p.

[13] Sheudzhen, A.H. (2003) Biogeohimija. Majkop: GURIPP «Adygeja», 1028 p.

[14] Anspok, P.I. (1990). Mikroudobrenija. Leningrad: Agropromizdat, 272 p.

[15] Wulkow, A., Pawelzik, E., Heckl, B. (2008). Effect of calcium and boron in potato tubers (Solanum tuberosum) of various cultivars differing in blackspot susceptibility. 
Conference of European Association for potato research. Potato for a changing world: 17th triential Conference of European Association for potato research: abstract of papers and posters. pp. 228--229.

[16] Dospehov, B.A. (1985). Metodika polevogo opyta (s osnovami statisticheskoj obrabotki rezul'tatov iss/edovanij), 5-e izd., dop. i pererab. Moscow: Agropromizdat, $351 \mathrm{p}$.

[17] Metodika issledovanij po kul'ture kartofelja. (1967). Moscow: NIIKH, 263 p.

[18] Starovoitova, O.A., Starovoitov, V.I., Manokhina, A.A. (2019). The Study of Physical and Mechanical Parameters of the Soil in the Cultivation of Tubers. Journal of Physics: Conference Series International Conference on Applied Physics, Power and Material Science. p. 012083.

[19] Lorh, A.G. (1948). Dinamika nakoplenija urozhaja kartofelja. Moscow: Sel'hozizdat, $191 \mathrm{p}$.

[20] Shpaar, D., Ivanjuk, V., Shuman, P., Postnikov, A. et al. (1999). Kartofel'. Minsk: FIAinform, 272 p.

[21] Nasibov, Hikmet Nasir ogly. (2013). Povyshenie jeffektivnosti vysokotochnogo vozdelyvanija kartofelja na dernovo-podzolistyh supeschanyh pochvah putjom minimizacii predposadochnoj obrabotki pochvy i differencirovannogo drobnolokal'nogo vnesenija udobrenij. PhD dissertation. Moskva: GNU VNIIKH Rossel'hozakademii.

[22] Shabanov, A.Je., Kiselev, A.I., Fedotova, L.S. (2018). Parametry potencial'noj urozhajnosti sortov kartofelja selekcionnogo centra VNIIKH. Zemledelie, no. 5, pp. 34--36. 